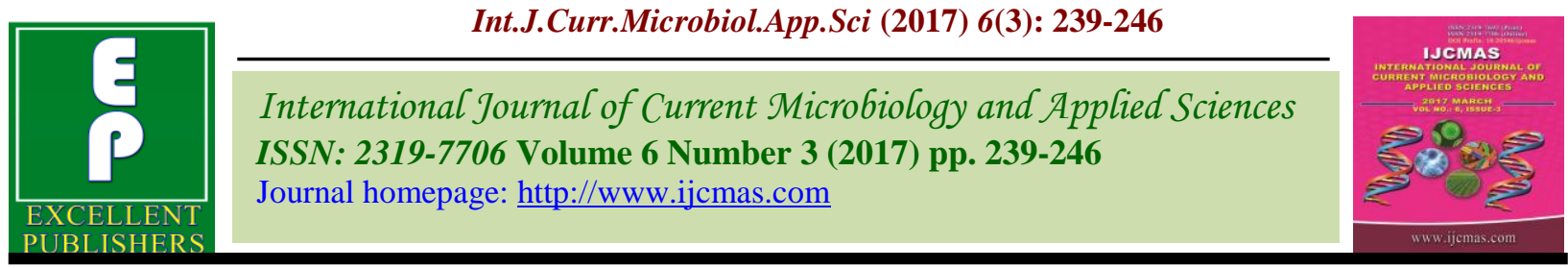

Original Research Article

https://doi.org/10.20546/ijcmas.2017.603.026

\title{
Genetic Analysis and RAPD Polymorphism in Wheat (Triticum aestivum L.) Genotypes
}

\author{
S.D. Tidke ${ }^{1 *}$ and P.S. Ranawade ${ }^{2}$ \\ ${ }^{1}$ MGM, Institute of Biosciences and Technology, Aurangabad, India \\ ${ }^{2}$ Modern College of Agricultural Biotechnology, Pune, India \\ *Corresponding author
}

\begin{abstract}
Keywords
Wheat, Genetic diversity, RAPD markers, Polymorphism.

\section{Article Info}

Accepted:

10 February 2017

Available Online:

10 March 2017
\end{abstract}

\section{A B S T R A C T}

Assessment of genotype diversity was studied using released and in pipeline genotypes of wheat, of these 22 were released and 14 were in pipeline. Genetic diversity among 36 wheat genotypes was studied using Random amplified polymorphic DNA (RAPD) analysis. 21 RAPD primers (RPI primers) were used for screening 36 wheat genotypes from which 2,868 fragments were amplified. It was observed that $63.3 \%$ bands were polymorphic and $36.4 \%$ were monomorphic. The percent of polymorphic bands in banding pattern was calculated and it was highest in RPI-22 (81.3\%) while lowest was recorded in RPI-2 (33.8\%) and highest PIC value was observed in RPI-22 and RPI-25 (0.88) while lowest in RPI-7 (0.70). Maximum fragments were produced in RPI-1 (200) and minimum in RPI-7 (82). In banding pattern some unique bands were seen, total 7 unique bands were observed. Genetic relationship between wheat genotypes was determined on the basis of Jackard IJ pair wise similarity coefficient values (Similarity coefficient values ranged from 0.09 to 0.99 ) and dendrogram was generated by UPGMA (Unweighted Pair Group Method with Arithmetic Mean) cluster analysis using dice's similarity matrix through NT-SYS pc software. From dendrogram 5 solitary and 8 clusters were revealed. From above analysis average coefficient values were revealed and highest (0.99) was observed between WSM-175.1 and WSM-163 genotypes while HD-2781 and NIAW-34 represent lowest average similarity coefficient value (0.09). The maximum similarity percentage i.e. $99 \%$ was found between WSM-175.1 and WSM-163 and the minimum similarity i.e. $09 \%$ was found between HD-2781 and NIAW-34.

\section{Introduction}

Wheat (Triticuma estivum L.) is an important cereal crop widely cultivated in India and world providing food calories and protein to the human population. Wheat is the annual plant belong to family Poaeceae (Singh et al., 2004). It is a good source of protein, minerals, vitamins (Thiamin, Riboflavin), sugar and fats. A protein in wheat varies from 7 to 24 per cent (Cauvain and Stanley, 2003). Triticum aestivum commonly contains three different but genetically related genomes (A, B and D) with total genomic size of $1.7 \times 10^{10}$ base pairs (Moore et al., 1995). Wheat occupies a place of prominence among other cultivated cereal crops in India. In view of possible implementation of plant varietal protection in India in the near future, increasing attention is being paid towards comprehensive characterization of elite Indian cereal germplasm, supplementing the existing 
morphological descriptors with reliable and repeatable DNA based marker profiles (Smith et al., 1991). The total number of accessions of wheat in international and local gene bank around the world is estimated to be in excess of 4,00,000 although many accessions may be duplicated in different collections (Poelham and Sleper, 1995). Thus, genetic diversity is important in a crop breeding programme for selection of suitable diverse parent to obtain heterotic hybrids as well as for the conservation and characterization of germplasm. Molecular marker provides information that helps to define the distinctiveness of species and their ranking according to the number of close relative and phytogenetic position. RAPD analysis has significant level of DNA polymorphism in different plant species. Factors such as speed and efficiency make RAPD a useful method for effective germplasm management to estimate genetic diversity (Sharma, 2006).

RAPD is well established genetic tool which provides a simple and fast approach to detect DNA Polymorphism for cultivars identification and diversity analysis (Welsh and McClelland, 1990) (Williams et al., 1990). RAPD is a dominant marker, RAPDPCR requires very small quantity of genomic DNA i.e. $10-15 \mu \mathrm{g} / \mathrm{ml}$ for assessment. Standard oligonucleotide (10 bp) long random sequence primer can be used to amplify the nanogram amount of total genomic DNA under low annealing temperature by PCR. Amplified product is generally separated on agarose gel electrophoresis (Bardakes et al., 2001). Because of simplicity and low cost of the RAPD technique it has wide range applications in many areas of biology. RAPD markers have been used to examine both interspecific and intraspecific variations in number of plant species (Nawroz, 2008), for Linkage studies (Williams et al., 1990), Gene tagging (Ranade et al., 2010), Plant and animal breeding, Population and evolutionary
genetices,Genetic mapping (Bardakes et al., 2001), DNA fingerprinting (Govardhanan et al., 2011) and high polymorphism that enables to generate many genetic markers within short time (Semagh et al., 2006).

\section{Materials and Methods}

\section{The plant material}

Representative plant samples of 36 accessions of Triticum aestivum were collected from NARP, Agriculture Research Station, Washim. Total 36 accessions were included in the study for analyzing genetic diversity of wheat (Table 1). All genotypes were planted in pots.

\section{DNA extraction}

Total genomic DNA was extracted using cetyltrimethyl ammonium bromide (CTAB) protocol given by (Doyle and Doyle, 1990) with some modifications. DNA was isolated from $0.5 \mathrm{~g}$ of fresh leaves of the 10-15 days seedlings. Tissue was crushed to a fine powder using liquid nitrogen and dispersed in $1 \mathrm{ml}$ pre warmed $\left(60^{\circ} \mathrm{C}\right)$ extraction buffer $(2 \%$ CTAB, $1.4 \mathrm{M} \mathrm{NaCl}, 20 \mathrm{mM}$ EDTA, pH 8.0, $100 \mathrm{mM}$ Tris-HCl, $\mathrm{pH} 8.0$ and $2 \% \quad \beta$ mercaptoethanol). After incubation for $1 \mathrm{hr}$ at $60^{\circ} \mathrm{C}$ with intermittent swirling, the mixture was emulsified with an equal volume of chloroform: isoamyl alcohol (24:1). Following centrifugation, the supernatant was collected and mixed with 0.6 volume of isopropanol. The precipitated nucleic acid was spooled out, washed twice in $70 \%$ ethanol, dried under vacuum, dissolved in TE buffer (10 mMTris-Cl, pH 8.0) and treated with RNase and proteinase $\mathrm{K}$ to remove RNA and protein respectively. DNA was tested for its quality and integrity on $0.8 \%$ agarose gel, quantified spectrophotometrically, diluted in TE buffer to a concentration of $25 \mathrm{ng} / \mu \mathrm{l}$ and utilized for PCR analysis. 


\section{RAPD procedure}

The PCR (Eppendorf, India) for RAPD analysis was performed according to (Williams et al., 1990) with certain modifications. Optimum conditions for DNA amplification were as follows. The reaction mixture was mixed well $25 \mu 1$ was distributed in each tube. $1 \mu 1$ of DNA $(25 \mathrm{ng} / \mu \mathrm{l})$ sample was added to each tube, mixed well and briefly centrifuged to collect drops from wall of tube, Master mix was prepared and divided into 36 equal parts (each of $12.5 \mu \mathrm{l}$ ) into 36 different PCR tubes. After that $10.5 \mu \mathrm{l}$ nuclease free water was added in each tube then $1 \mu \mathrm{l}$ primer and $1 \mu \mathrm{l}$ of 36 different genomic DNA samples of wheat were added to each tube that leads to final quantity of $25 \mu$ l. PCR tubes were then placed in thermal cycler for amplification of the genomic DNA. The PCR protocol for RAPD markers was standardized for analyzing the samples of wheat as pre heat $101^{\circ} \mathrm{C}, 94^{\circ} \mathrm{C}$ for $5 \min (1$ cycle), $94^{\circ} \mathrm{C}$ for $45 \mathrm{sec}, 35^{\circ} \mathrm{C}$ for $1 \mathrm{~min}, 72^{\circ} \mathrm{C}$ for $1.5 \mathrm{~min}(10 \mathrm{cycles}), 94^{\circ} \mathrm{C}$ for $45 \mathrm{sec}, 38^{\circ} \mathrm{C}$ for $1 \mathrm{~min}, 72^{\circ} \mathrm{C}$ for $1 \mathrm{~min}$ (30 cycles), and $72^{\circ} \mathrm{C}$ for $10 \mathrm{~min}(1$ cycle $)$ and $4^{0} \mathrm{C}$ for $10 \mathrm{~min}$. PCR Amplification was performed in a $25 \mu \mathrm{l}$ reaction mixture volume containing $25 \mathrm{ng}$ of DNA, 10x buffer, 10mMdNTPs, 100ng/ $\mu$ l of primer, $2 \mathrm{mM}$ of magnesium chloride and $3 \mathrm{U} /$ $\mu \mathrm{l}$ of Taq (Thermus aquaticus) DNA polymerase enzyme (GENEI, Bangalore). Single RPI primer (Table 2) was included in each $\mathrm{PCR}$ reaction.

\section{Data analysis}

Submerged gel electrophoresis unit was used for fractionating RAPD markers on $2 \%$ agarose gel. $4 \mu 1$ loading dye was added to the amplified products in each tube and mixed well. $20 \mu \mathrm{l}$ of amplified products of each sample were loaded on $2 \%$ agarose gel containing $1 \mathrm{x}$ TAE buffer to separate the amplified fragments. The Gene ruler 100bp
DNA ladder plus was used as the standard to determine the size of the polymorphic fragments. The gel was visualized under UV transilluminator (JASCO) and photographed using Gel-Doc system (UV-Tech Ltd).The amplified fragment profiles were visually scored for the presence (1) or absence (0) of bands and entered in a scoring matrix. Jaccard's similarity coefficients were calculated and used to construct dendrograms based on UPGMA and SAHN clustering. The computer package NT SYS-pc version 2.1 was used to carry out cluster analysis. Polymorphic and Monomorphic amplified fragments were counted from PCR amplification image and percentage of the same was calculated by the given formula:

Polymorphic percent $(\%)=$

$$
\frac{\text { Polymorphic Bands }}{\text { Total Bands }} \times 100
$$

\section{Results and Discussion}

Genetic Analysis and RAPD Polymorphism in Wheat Genotypes was carried out using RAPD primers. The results obtained are presented under following points:

\section{Selection of suitable RAPD primers}

Universal primers of RPI series were used to evaluate polymorphism of 36wheat genotypes. PCR amplified products of each primer were resolved on $2 \%$ agarose gel and the size of the amplified products was compared with marker DNA. 21 primers were screened.

\section{Band statistics}

Universal random primers like RPI-1, RPI-2, RPI-3, RPI-4, RPI-5, RPI-6, RPI-7, RPI-9, RPI-10, RPI-11 RPI-12, RPI-14, RPI-15, RPI16, RPI-17, RPI-18, RPI-19, RPI-22, RPI-23, 
RPI-24, RPI-25, were used, 2,868 RAPD amplified fragments were generated. Among RAPD markers, RPI-1 produced maximum number of fragments (200 from all genotypes) followed by RPI-22 (192) and RPI-11 (185) while RPI-7 and RPI-23 generated minimum number of fragments (82) and (87) respectively in the genomic pool. Higher numbers of polymorphic fragments were observed inRPI-22 (156) and lower in RPI-7 (46) and their percentage were calculated which was highest in RPI-22 (81.3\%) and lowest in RPI-2 (33.8\%). Polymorphism information content (PIC) was calculated and highest PIC value was observed in RPI-22 and RPI-25 (0.88) and lowest was observed in RPI-7 (0.70). Higher number of monomorphic fragments (108) were observed in RPI-3 and RPI-6 and the percent of monomorphic fragments in banding pattern was calculated which was highest in RPI-2 (66.2\%) while lowest was recorded from RPI-11 (19.5\%). Some unique bands were observed in specific genotypes, total 7 numbers of unique bands were observed in RPI-4 (1), RPI-5 (1), RPI-12 (1), RPI-14 (1) and RPI-15 (1), RPI-10 (2), in genotypes HD-2987, WSM-184, WSM-175.1, WSM-175.1, WSM-175.1, WSM-175.1 and HD-2987 respectively (Table 3).

Table.1 Characteristics of wheat genotypes

\begin{tabular}{|l|c|c|l|c|c|}
\hline Genotype & aestivum/durum & $\begin{array}{c}\text { Released/ In } \\
\text { pipe line }\end{array}$ & Genotype & aestivum/durum & $\begin{array}{c}\text { Released/ In } \\
\text { pipe line }\end{array}$ \\
\hline AKDW 2997.16 & T. durum & Released & $\begin{array}{l}\text { PDKV } \\
\text { Washim 1472 }\end{array}$ & T. aestivum & Released \\
\hline MACS 1967 & T. durum & Released & NIAW 34 & T. aestivum & Released \\
\hline N 59 & T. durum & Released & NIAW 1415 & T. aestivum & Released \\
\hline Agra Local & T. durum & Released & NI 5439 & T. aestivum & Released \\
\hline AKDW 2997 & T. durum & Released & WSM 55 & T. aestivum & In Pipe line \\
\hline FLW 9 & T. aestivum & Released & WSM 163 & T. aestivum & In Pipe line \\
\hline FLW 20 & T. aestivum & Released & WSM 105 & T. aestivum & In Pipe line \\
\hline HD 2987 & T. aestivum & Released & WSM 42 & T. aestivum & In Pipe line \\
\hline KITE & T. aestivum & Released & WSM 1472 & T. aestivum & In Pipe line \\
\hline PUSA & T. aestivum & Released & WSM 175.1 & T. aestivum & In Pipe line \\
\hline HD 2781 & T. aestivum & Released & WSM 175.7 & T. aestivum & In Pipe line \\
\hline PKV Washim & T. aestivum & Released & WSM 103 & T. aestivum & In Pipe line \\
\hline AKW 3722 & T. aestivum & Released & WSM 135 & T. aestivum & In Pipe line \\
\hline AKW 1071 & T. aestivum & Released & WSM 133 & T. aestivum & In Pipe line \\
\hline MACS 6222 & T. aestivum & Released & WSM 51 & T. aestivum & In Pipe line \\
\hline MACS 2496 & T. aestivum & Released & WSM 184 & T. aestivum & In Pipe line \\
\hline LOK 1 & T. aestivum & Released & WSM 155 & T. aestivum & In Pipe line \\
\hline HD 2189 & T. aestivum & Released & WSM 174.1 & T. aestivum & In Pipe line \\
\hline
\end{tabular}


Table.2 Universal RPI primers (GENEI Biotech Pvt. Ltd. Bangalore)

\begin{tabular}{|c|c|l|l|l|l|}
\hline Primers & $\begin{array}{c}\text { Accession } \\
\text { No. }\end{array}$ & Sequence 5' -3' $^{\prime}$ & Primers & $\begin{array}{c}\text { Accession } \\
\text { No. }\end{array}$ & Sequence 5' -3' $^{\prime}$ \\
\hline RPI 1 & AM765819 & AAAGCTGCGG & RPI 14 & AM773774 & ACTTCGCCAC \\
\hline RPI 2 & AM750044 & AACGCGTCGG & RPI 15 & AM773775 & AGCCTGAGCC \\
\hline RPI 3 & AM773310 & AAGCGACCTC & RPI 16 & AM773776 & AGGCGGCAAG \\
\hline RPI 4 & AM773769 & AATCGCGCTG & RPI 17 & AM911710 & AGGCGGGAAC \\
\hline RPI 5 & AM773770 & AATCGGGCTG & RPI 18 & AM765830 & AGGCTGTGTC \\
\hline RPI 6 & AM773771 & ACACACGCTG & RPI 19 & AM773777 & AGGTGACCGT \\
\hline RPI 7 & AM773312 & ACATCGCCCA & RPI 22 & AM911711 & CATAGAGCGG \\
\hline RPI 9 & AM773315 & ACCGCCTATG & RPI 23 & AM911712 & CCAGCAGCTA \\
\hline RPI 10 & AM750045 & ACGATGAGCG & RPI 24 & AM765821 & CCAGCCGAAC \\
\hline RPI 11 & AM911709 & ACGGAAGTGG & RPI 25 & AM750054 & GAGCGCCTTC \\
\hline RPI 12 & AM773316 & ACGGCAACCT & \multicolumn{4}{|l}{} \\
\hline
\end{tabular}

Table.3 Characteristics of amplified fragments obtained from 21 primers for RAPD analysis of wheat genotypes

\begin{tabular}{|c|l|c|c|c|c|c|c|c|}
\hline $\begin{array}{c}\text { Sr. } \\
\text { No. }\end{array}$ & Primers & $\begin{array}{c}\text { Mono- } \\
\text { morphic } \\
\text { Bands }\end{array}$ & $\begin{array}{c}\text { Mono- } \\
\text { morphic } \\
\text { percent (\%) }\end{array}$ & $\begin{array}{c}\text { Poly- } \\
\text { morphic } \\
\text { Bands }\end{array}$ & $\begin{array}{c}\text { Poly- } \\
\text { morphic } \\
\text { percent (\%) }\end{array}$ & $\begin{array}{c}\text { Unique } \\
\text { Bands }\end{array}$ & $\begin{array}{c}\text { Total } \\
\text { Bands }\end{array}$ & $\begin{array}{c}\text { PIC } \\
\text { Values }\end{array}$ \\
\hline 1 & RPI-1 & 72 & $36.0 \%$ & 128 & $64.0 \%$ & - & 200 & 0.87 \\
\hline 2 & RPI-2 & 108 & $66.2 \%$ & 55 & $33.8 \%$ & - & 163 & 0.81 \\
\hline 3 & RPI-3 & 36 & $32.7 \%$ & 74 & $67.3 \%$ & - & 110 & 0.79 \\
\hline 4 & RPI-4 & 72 & $55.8 \%$ & 56 & $43.4 \%$ & 01 & 129 & 0.80 \\
\hline 5 & RPI-5 & 36 & $24.8 \%$ & 108 & $74.5 \%$ & 01 & 145 & 0.85 \\
\hline 6 & RPI-6 & 108 & $65.1 \%$ & 58 & $34.9 \%$ & - & 166 & 0.83 \\
\hline 7 & RPI-7 & 36 & $43.9 \%$ & 46 & $56.1 \%$ & - & 82 & 0.70 \\
\hline 8 & RPI-9 & 36 & $29.8 \%$ & 85 & $70.2 \%$ & - & 121 & 0.84 \\
\hline 9 & RPI-10 & 36 & $32.1 \%$ & 74 & $66.1 \%$ & 02 & 112 & 0.82 \\
\hline 10 & RPI-11 & 36 & $19.5 \%$ & 149 & $80.5 \%$ & - & 185 & 0.87 \\
\hline 11 & RPI-12 & 36 & $31.3 \%$ & 78 & $67.8 \%$ & 01 & 115 & 0.78 \\
\hline 12 & RPI-14 & 72 & $42.9 \%$ & 95 & $56.5 \%$ & 01 & 168 & 0.85 \\
\hline 13 & RPI-15 & 36 & $31.3 \%$ & 77 & $66.9 \%$ & 01 & 115 & 0.81 \\
\hline 14 & RPI-16 & 36 & $33.0 \%$ & 73 & $66.9 \%$ & - & 109 & 0.78 \\
\hline 15 & RPI-17 & 36 & $34.6 \%$ & 68 & $65.4 \%$ & - & 104 & 0.78 \\
\hline 16 & RPI-18 & 72 & $55.4 \%$ & 58 & $44.6 \%$ & - & 130 & 0.80 \\
\hline 17 & RPI-19 & 36 & $27.1 \%$ & 97 & $72.9 \%$ & - & 133 & 0.81 \\
\hline 18 & RPI-22 & 36 & $18.8 \%$ & 156 & $81.3 \%$ & - & 192 & 0.88 \\
\hline 19 & RPI-23 & 36 & $41.4 \%$ & 51 & $58.6 \%$ & - & 87 & 0.75 \\
\hline 20 & RPI-24 & 36 & $30.5 \%$ & 82 & $69.5 \%$ & - & 118 & 0.81 \\
\hline 21 & RPI-25 & 36 & $19.6 \%$ & 148 & $80.4 \%$ & - & 184 & 0.88 \\
\hline & Total & 1044 & $36.4 \%$ & 1816 & $63.3 \%$ & 07 & 2868 & - \\
\hline
\end{tabular}


Fig.1 Fragments obtained from RPI-1 over 36 wheat genotypes

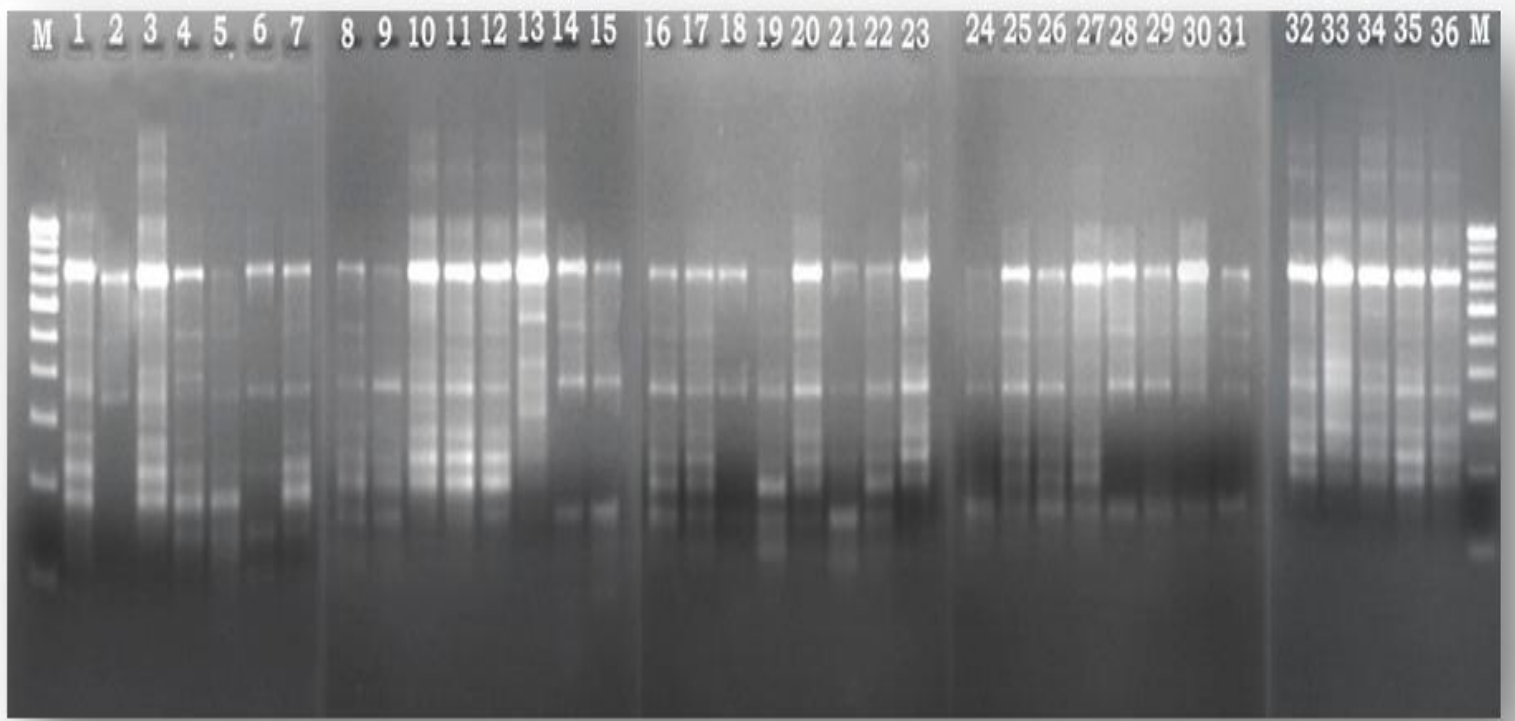

Fig.2 Fragments obtained from RPI-25 over 36 wheat genotypes

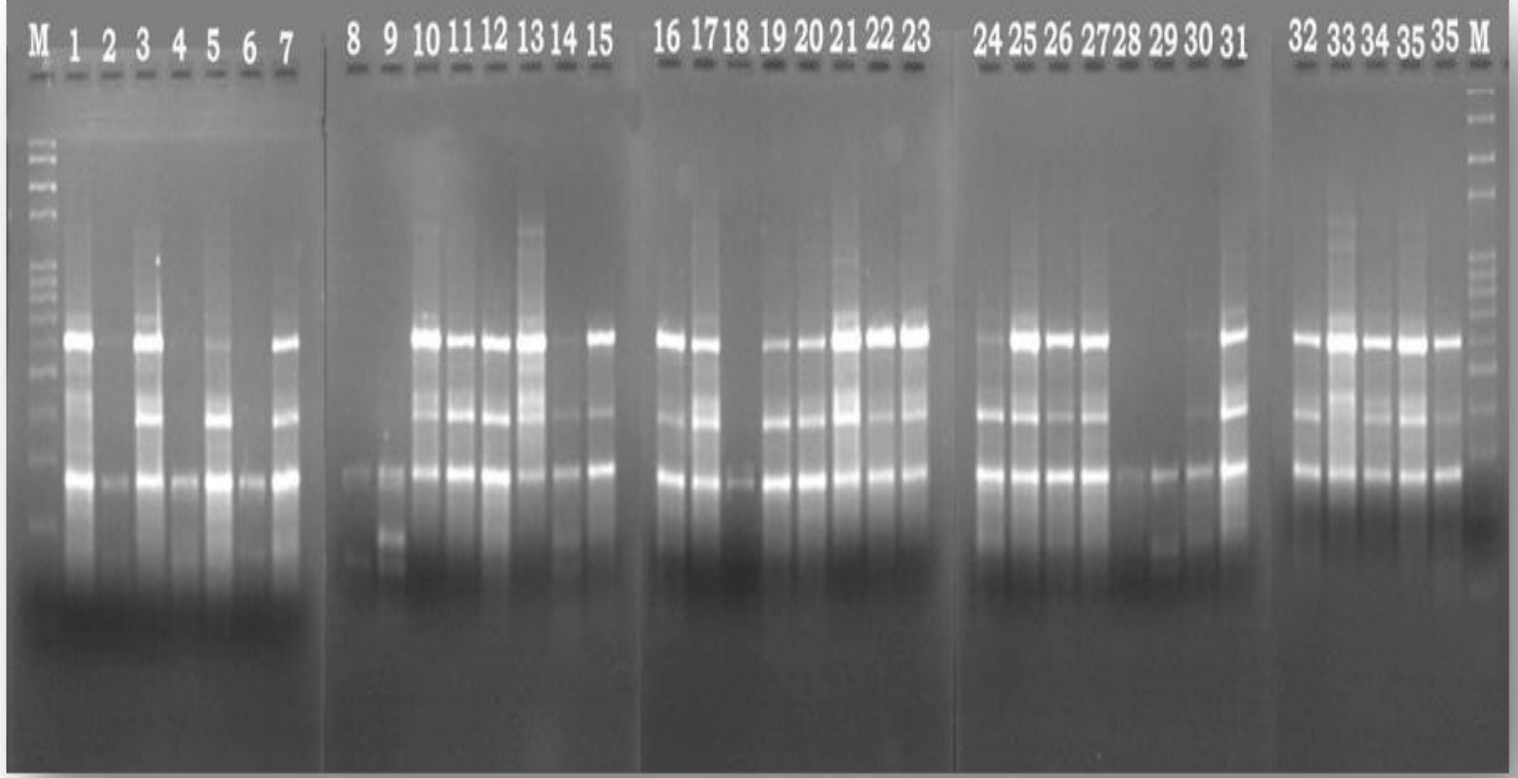


Fig.3 Dendrogram generated by UPGMA cluster analysis showing genetic diversity among the different wheat genotypes

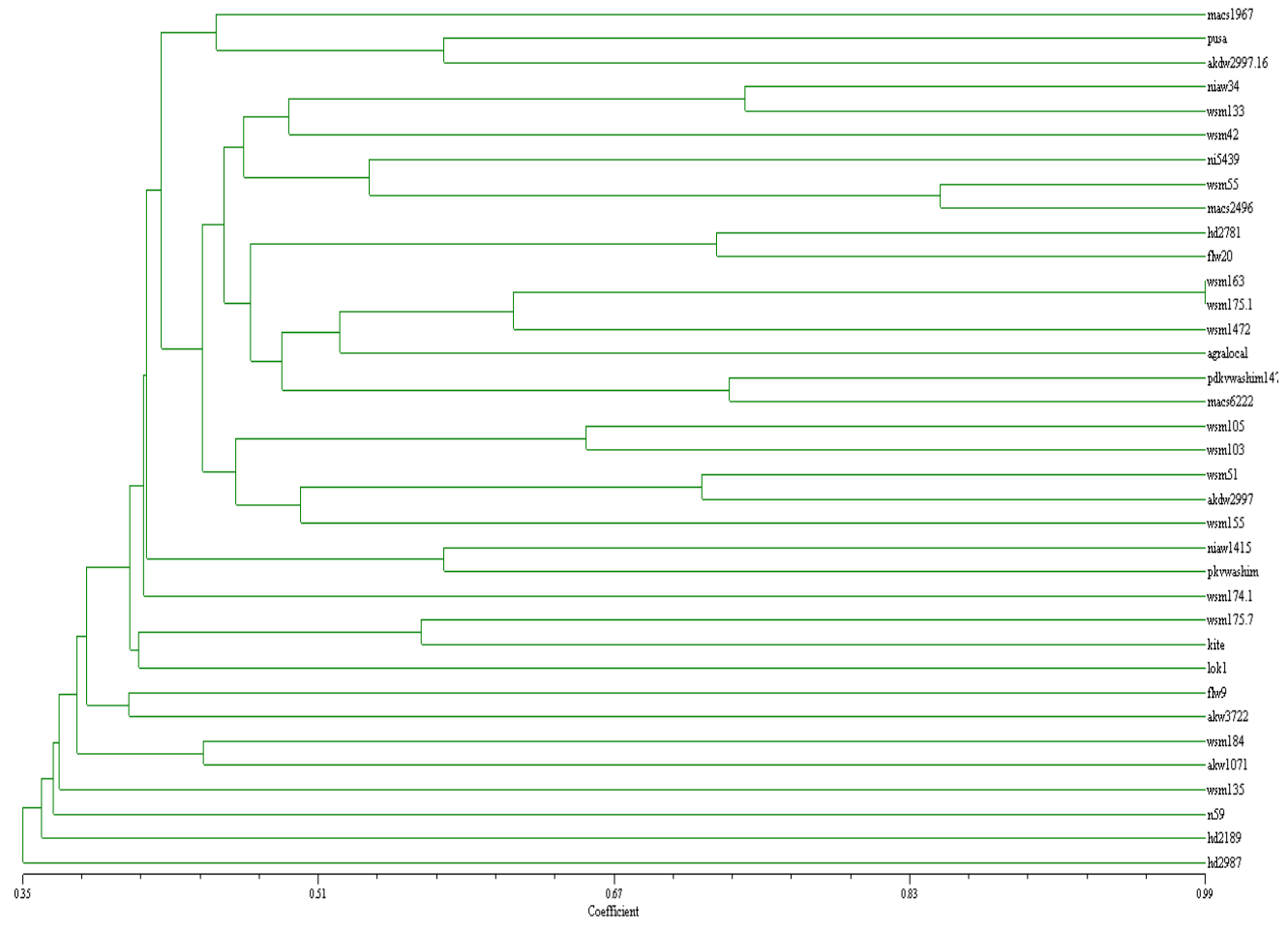

\section{Cluster analysis}

A Dendrogram was generated by UPGMA cluster analysis based on Jackard IJ similarity coefficients and cluster analysis on the basis of coefficient value, the accessions further divided into 5 solitary and 8 clusters which are divided further into different genotypes. First cluster contains 3 genotypes(MACS1967, Pusa, AKDW-2997.16) second, 6 genotypes (NIAW-34, WSM-133, WSM-42, NI-5439, WSM-55, MACS-2496) third, 8 genotypes (HD-2781, FLW-20, WSM-163, WSM-175.1, WSM1472, Agra Local, PDKV washim-1472, MACS-6222) fourth, 5 genotypes (WSM-105, WSM-103, WSM-51, AKDW-2997, WSM-155) fifth, 2 genotypes (NIAW-1415, PDKV washim) sixth, 3 genotypes, (WSM-175.7, Kite, Lok-1) seventh, 2 genotypes, (FLW-9, AKW-3722) and eighth contain 2 genotypes (WSM-184, AKW-1071).
Similarity based on Jackard IJ coefficient

Genetic relationship between wheat genotypes were determined on the basis of Jackard IJ pair wise similarity coefficient values. The value of similarity coefficient ranged from 0.09 to 0.99 . GenotypesWSM175.1 and WSM-163 represent highest average similarity coefficient value (0.99) genotypes HD-2781 and NIAW-34 represent lowest average similarity coefficient value (0.09). The maximum similarity coefficient percentage i.e. $99 \%$ was found between WSM-175.1 and WSM-163 and the lowest i.e. 9\% was found between HD-2781 and NIAW-34. Thus, RAPD plays an important role in securing plant variety right by virtue of its unique efficiency in distinguishing closely related germplasm. Future thrust will be directed towards the holistic use of RAPD primes for DNA fingerprinting, genetic analysis and linkage mapping in wheat. 


\section{Acknowledgement}

The authors wish to thank Dr. S. N. Harke, (Director, MGM Institute of Biosciences and Technology, Aurangabad) for granting me permission to work in this esteemed Institute Dr. B. D. Gite, (Officer in-charge, Agriculture research station, Washim) and Mr. S. V. Shinde (senior research assistant at the Agriculture research station) for providing the different genotype of wheat from the Agriculture research station, Washim and our heartfelt thanks to parents for their motivation and encouragement.

\section{References}

Bardakes, F. 2001. Random amplified polymorphic DNA (RAPD) marker. Turk. J. Biol., 25: 185-196.

Cauvain, P. and Stanley, P. 2003. Bread Making. CRC Press, 540-543.

Doyle, J.J. and Doyle, J.L. 1990. Isolation of plant Vigna leaves. The amount of DNA recovered per gram of DNA from fresh tissue. Focus, 12: 13-15.

Govarthanan, M., Guruchandar, A., Arunapriya, S., Selvankumar, T. and Selvam, K. 2011.Genetic variability among Coleus sp. studied by RAPD banding pattern analysis. Int. J. Biotechnol. Mol. Biol. Res., 2(12): 202-208.

Moore, G., Devos, K., Wang, Z. and Gale, M. 1995. Cereal genome evolution. Curr. Biol., 5: 737-739.

Nawroz Abdul-Razzak Tahir. 2008. Assessment of Genetic diversity among wheat varieties in sulaimanyah using Random Amplified Polymorphic DNA (RAPD) analysis. Jordan J. Biol. Sci., 1(4): 159164.

Poelham, J. and Sleper, D. 1995. Breeding of field crops. $4^{\text {th }}$ edition. Panima Corporation, New Delhi, 207-213.

Ranade, S., Farooqui, N., Bhattacharya, E. and Verma, A. 2010. Gene Tagging with Random Amplified Polymorphic DNA (RAPD) Markers for Molecular Breeding in Plants. Crit. Rev. Plant Sci., 20(3): 2001.

Semagh, K., Bjornstad, A. and Ndjiondjop, M. 2006. An overview of molecular marker method for plants. African J. Biotechnol., 5(25): 2540-2568.

Sharma, R., Thomas,G., Mohapatra,T. and Rao, A. 2006. Distinguishing Indian commercial wheat varieties using RAPD based DNA fingerprints. Indian $J$. Biotechnol., 5: 200-206.

Singh, R., Singh, P. and Chidda, S. 2004. Modern techniques of rising field crops. Oxford and IBH publishing, 229-230.

Smith, J.S., Smith, O., Bowen, S., Tenborg, R. and Walls, S.1991. The description and assessment of distances between inbred lines of maize: A revised scheme for testing of distinctiveness between inbred lines utilizing RFLP. Maydica, 36: 213216.

Welsh, J. and McClelland, M. 1990. Fingerprinting genomes using PCR with arbitrary primers. Nucleic Acids Res., 18: 7213-7218.

Willims, J., Kubelik, A., Livak, K., Ski, J. and Tingey, S. 1990. DNA polymorphisms amplified by arbitrary primers are useful as genetic markers. Nucleic Acids, 18: 6531-6535.

\section{How to cite this article:}

Tidke, S.D. and Ranawade, P.S. 2017. Genetic Analysis and RAPD Polymorphism in Wheat (Triticum aestivum L.) Genotypes. Int.J.Curr.Microbiol.App.Sci. 6(3): 239-246. doi: https://doi.org/10.20546/ijcmas.2017.603.026 